\title{
夏季高温期におけるトマトのポット育苗において根域冷却の時間帯が 生育および収量に及ぼす影響
}

\author{
木下貴文*・中野善公 ${ }^{a} ・ 川$ 川嶋浩樹 \\ 農業・食品産業技術総合研究機構近畿中国四国農業研究センター 765-8508 香川県善通寺市仙遊町
}

\section{Effect of Duration of Root-zone Cooling in Potted Tomato Seedlings on Plant Growth and Fruit Yield during High-temperature Periods}

\author{
Takafumi Kinoshita*, Yoshihiro Nakano ${ }^{\mathrm{a}}$ and Hiroki Kawashima \\ NARO Western Region Agricultural Research Center, Senyu-cho, Zentsuji, Kagawa 765-8508
}

\begin{abstract}
In order to improve the quality of tomato nursery plants in high-temperature periods, we investigated the effect of root-zone cooling of the potted seedlings on growth, establishment, and subsequent fruit yield. We utilized cold water passed through a heat exchange pipe which contacted the pot surface of tomato seedlings to reduce the growing medium temperature. The root growth was enhanced by continuous ( $24 \mathrm{~h}$ ) cooling, while both shoot and root growths were enhanced by daytime (7:00 19:00) cooling. On the other hand, night-time (19:00 7:00) cooling repressed shoot growth. Enhanced root growth by root-zone cooling improved plant establishment. Moreover, daytime root-zone cooling during the pot seedling stage increased the subsequent fruit yield. Daytime root-zone cooling for $8 \mathrm{~h}(9: 00 \sim 17: 00)$ had nearly the same effects as those for $12 \mathrm{~h}(7: 00 \sim 19: 00)$. Based on the above findings, under this experimental condition, tomato seedlings with a high yield potential in a low-node-order pinching system at a high planting density could be produced by cooling the center of the medium by $3 \sim 4{ }^{\circ} \mathrm{C}$ during particularly hightemperature hours.
\end{abstract}

Key Words : fruit yield, hydroponics, root-zone temperature, spot cooling キーワード : 果実収量, 根域温度, 局所冷房, 養液栽培

\begin{abstract}
緒言
近年の施設園芸生産では, 効率的な利用のために栽培施設 が周年にわたって利用されるよらになり, 植物の生育適温を 上回るよらな夏季高温期に䋆ても栽培が行われている。 ト マトに関しても, 従来からの作型である抑制栽培や促成栽培 に加えて, 最近は年に数回作付けを行ら低段密植栽培技術の 開発や普及が進んでいるため, 夏季高温期に育苗を行らこと が多い，さらに，現在のトマト栽培では，黄化葉巻病を引き 起こすウイルスを伝播するコナジラミの侵入を防ぐため, $0.4 \mathrm{~mm}$ 以下の非常に目の細かい防虫ネットを展張するのが 一般的となって扮り, 換気効率が低下寸ることで施設内がま すます高温となりやすい状況になっている。

一般に，夏季高温期は生育の抑制，徒長や活着不良など によって苗の品質が低下しやすいため，何らかの暑熱対策 が必要であると考光られる。 トマトを含めて様々な作物に 打ける暑熱対策として最も一般的なものは遮光である。ま
\end{abstract}

2012 年 3 月 10 日 受付. 2012 年 6 月 22 日 受理.

* Corresponding author. E-mail: takino@affrc.go.jp

a 現在 : 農業・食品産業技術総合研究機構花き研究所
た，トマト育苗に拉ける個別技術としては，高冷地育苗 （Oda ら，2005），夜冷育苗（岩瀬ら，1983; 木村ら，1978; 桜井ら，1978），熱線遮蔽フィルムの展張による高温抑制 （吉島ら，2008）などの技術が開発されてきた. しかし，ト マトでは遮光によって生育の抑制や着花数の減少が起こる （齋藤，2004）可能性があるため，日射量が多いときの久遮 光するよらに制御するといった必要があり，そのための装 置にコストがかかる，また，高冷地育苗は苗の運搬に，夜 冷育苗のような施設全体の冷却は設備やエネルギーにコス トが多くかかるといった制限要因があるなど，広く普及し ている技術は少ない。一方，近年，完全閉鎖型の人工環境 下で育苗を行ら閉鎖型苗生産システムが開発され（大山ら， 2003)，周年で安定した苗生産が可能となった。 しかし，こ の方式では庫内スペースやコストの関係から，現状に拈い て導入が可能であるのは植物体が小さなセル育苗に限られ ている（土屋，2007）.

以上のように，既存の技術は主に施設全体や植物体全体 の冷却に主眼が置かれて扣り，コスト面などから普及に至 らない場合が多かったと考觉られる。そこで本研究では, トマトのポット育苗に拈いて, 根域のみの冷却に着目した. 根域の温度制御は比較的コストがかからず容易であり，ト 
マト, イチゴ, ホウレンソウなぞでは, 本國の根域冷却に よる生育の促進, 増収や開花の前進化などが報告されてい る（Ikeda ら, 2007; Lee・Takakura, 1994; 佐々木, 1991; 佐々 木・板木, 1989; 山崎ら，2007; 安場ら，2006）。ポット育 苗を行ら場合についても, 根域が隔離されていて容積が少 ないため, 根域のみの冷却が容易であり, 施設全体の冷却 に比べて低コストであると考光られる。 パンジーおよびミ ニシクラメンの育苗では気化冷却による根域冷却によって 生育が促進されることが報告されている（中野ら，2009）. ロックウールポットを用いたトマトの育苗に打いても, 根 域冷却によって苗の生育や活着が促進されたといら報告 （和田，2004）があるが，知見が少なく効果は明らかとなっ ていない。

根域の温度管理は, サーモスタットなどを用いて 24 時間 一定の温度に設定して加温や冷却を行らことが一般的であ る. 一方, 省エネ・省資源や低コスト化の観点からは, 生 育の促進なぞに効果的な時間帯の久根域の温度制御を行ら ことが有効であると考兄られ，根域加温の場合には昼間の 加温が生育促進に効果的であるといら報告がみられる(Ali ら，1994; Gent・Ma, 2000; 木下ら，2010)。しかし，根域の 冷却に関してはそのような報告は見当たらず，生育促進な ぞに効果的な時間帯を明らかにする必要がある.

そこで本研究では，広く用いられている黒色ポリエチレ ン製ポットによる夏季高温期のトマト育苗に打いて, 根域 冷却括よびその時間帯が苗の生育, 低段密植栽培条件下に おける定植後の活着および果実収量に及ぼす影響について 検討した.

\section{材料および方法}

\section{1. 耕種概要および根域の冷却方法}

実験は近畿中国四国農業研究センター内のプラスチック フィルムを展張した鉄骨八ウス（香川県善通寺市）で行っ た. 材料としてトマト (Solanum lycopersicum L.) “桃太郎 ファイト’（タキイ種苗）を用いた．育苗にはエブアンドフ ロー式の栽培ベンチ（カネコ High \& Low Ponic, カネコ種 苗）を用いた。催芽種子を育苗培養土（与作 N150，JA 全 農）が充填された 128 穴セルトレーに播種し, 本葉 3.5 枚 展開期まで, 1 日 2 回水道水を灌水して管理を行った後, バーク堆肥（天領 $\mathrm{CB}$ 培地, ジャパングリーンシステム) を充填した $9 \mathrm{~cm}$ 径の黒色ポリエチレン製ポットに鉢上げを 行った。 ポット育苗時には大塚 $\mathrm{A}$ 処方 $1 / 2$ 単位濃度培養液 を 1 日 3 回（9:00，12:00 および 15:00）灌水した. 鉢上げ 直後より定植まで下記の方法による根域冷却処理を行っ た. 根域冷却は育苗ベンチ底面に内径 $13 \mathrm{~mm}$, 外径 $18 \mathrm{~mm}$ の塩化ビニール製パイプをポットの両脇に接するように設 置し, 冷水循環器 (LV-200, アドバンテック東洋) で $15^{\circ} \mathrm{C}$ に設定したタンク $(50 \mathrm{~L})$ 内の冷却水を毎分約 $15 \mathrm{~L}$ の流量 でパイプ内に常時循環することで行った (第 1 図). 本葉 7 $\sim 8$ 枚展開期のポット育苗終了後には, 前述のバーク堆肥

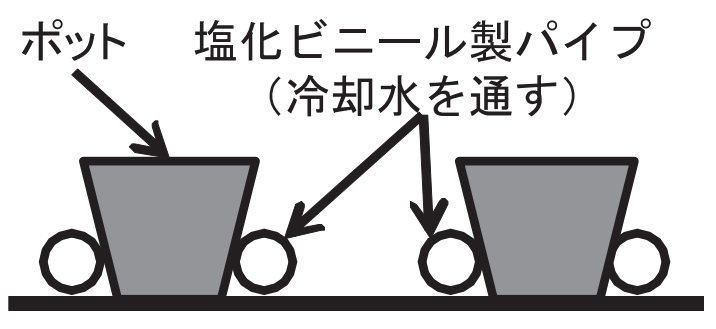

第 1 図 根域の冷却方法の概要

を充填したプランター $(64 \times 22 \times 18 \mathrm{~cm})$ にプランター 1 個 当たり 6 株を株間 $10 \mathrm{~cm}$ で定植した(培地量約 $2.5 \mathrm{~L} /$ 株). プランターは南北方向に配置し, 㖕間を $180 \mathrm{~cm}$ として 1 条 振り分けで誘引を行い, 栽植密度は 5,555 株 $/ 10 \mathrm{a}$ であっ た. 培養液管理は大塚 $\mathrm{A}$ 処方 $1 / 2$ 単位濃度培養液で掛け流 乙式の点滴給液を行い, 第 3 果房上 2 葉を残して摘心を行っ た. 各果房とも 3 花程度が開花したときにトマトトーン 100 倍液を噴霧し, 果房当たり 5 果以内に摘果した。 八ウス内 の温度管理は，育苗期間中は常時側空を開放した状態を保 ち，定植後は，八ウス内が $25^{\circ} \mathrm{C}$ 以上となった場合に側空 を開放して換気を行った。 ハウスの側面には $0.4 \mathrm{~mm}$ 目合 いの防虫ネットを展張した。

\section{2. 根域冷却の時間帯が苗の生育および定植後の果実収量 に及ぼす影響（実験 1)}

2009 年 6 月 26 日からセル育苗を行い, 7 月 14 日にポッ 卜に鉢上げして冷却処理を開始した. 根域冷却処理として, 終日冷水を流して冷却する「終日冷却区」，7:00～19:00の 久冷水を流して冷却する「昼間冷却区」, 19:00～7:00のみ 冷水を流して冷却する「夜間冷却区」拈よび冷却処理を行 わない「無処理区」の 4 処理区を設定した。ポット育苗期 間中は, 八ウス中央付近の気温（通風条件，高さ $1.8 \mathrm{~m}$ ), 冷却水タンク内の水温执よびポット内の培地中央部付近 （培地表面から深さ約 $4 \mathrm{~cm}$ ）の根域温度（各区 2 株）につ いて, $\mathrm{T}$ 型熱電対で 1 分ごとに測定し， 10 分間の平均値と してデータロガー（ZR-RX40，オムロン）に記録した. 2 週間後の 7 月 28 日に各区 10 個体について苗の茎長, 乾物 重などの生育を調査した後, 定植を行った。定植後の栽培 試験は 1 区 6 株の 3 反復乱塊法で行った。果実を 1 週間に 2 回収穫し, $80 \mathrm{~g}$ 以上の正常果（可販果）と $80 \mathrm{~g}$ 未満の小 果打よび生理障害果に分け，それぞれの 1 果重拈よび個数 を調査した.

石川・山中（2009）拉よび島ら（2008）の方法を参考に して, 以下の方法で苗の引き抜き抵抗值を調査し，定植後 の活着程度の指標とした．植え穴に十字に結んだビニール ひもを設置した上からポット苗の培地が接するように定植 し，地表に出たひもの端部を株元で十字に結んだ．ひもの 結束部分をデジタルフォースダージ（AD-4932A-50N, エー・アンド・デイ）でゆっくりと引き抜き，定植培地か ら苗が引き抜かれるまでの最大加重值を記録した，苗の重 さの影響を排除するため, 最大加重值を調査する際には地 
上部を切除した. 各区 4 株 $\times 3$ 反復を対象に調査し, 定植 1 週間後の最大加重值から定植直後の最大加重值を引いたも の引き抜き抵抗值とした。

\section{3. 昼間の根域冷却時間の長さが苗の生育および定植後の 果実収量に及ぼす影響（実験 2）}

2010 年 6 月 25 日からセル育苗を行い， 7 月 14 日にポッ トに鉢上げして冷却処理を開始した. 根域冷却処理として, 7:00〜 19:00 の夕冷水を流して冷却する「12 h 冷却区」, 9:00 〜 17:00 の久冷水を流し冷却する「8h 冷却区」打よび冷却 処理を行わない「無処理区」の 3 処理区を設けた．２週間 後の 7 月 28 日に各区 10 個体について実験 1 と同様に苗の 生育を調査した後, 定植を行った. 定植後の調查も実験 1 と同様に行った。

\section{結 果}

\section{1. 根域冷却の時間帯が苗の生育および定植後の果実収量 に及ぼす影響（実験 1）}

第2図にポット育苗期間平均での根域温度などを示した。 冷却水温は昼間に設定值よりもやや上昇したが，最高 $18.6^{\circ} \mathrm{C}$, 最低 $14.8^{\circ} \mathrm{C}$ で推移し, 日平均水温は $15.6^{\circ} \mathrm{C}$ であっ た. 根域冷却を行った時間帯の平均根域温度を久ると, 昼 間冷却区 $(7: 00 \sim 19: 00)$ では無処理区 $\left(33.7^{\circ} \mathrm{C}\right)$ より $4.6^{\circ} \mathrm{C}$ 低い $29.1^{\circ} \mathrm{C}$, 夜間冷却区（19:00～7:00）では無処理区 $\left(27.1^{\circ} \mathrm{C}\right)$ より $4.4^{\circ} \mathrm{C}$ 低い $22.7^{\circ} \mathrm{C}$ であった. 冷却を行わない 時間帯については，無処理区とほぼ同じ温度で推移した。 終日冷却区では昼間 $\left(28.8^{\circ} \mathrm{C}\right)$ 扤よび夜間 $\left(22.5^{\circ} \mathrm{C}\right)$ とも 飞昼間冷却区あるいは夜間冷却区とほぼ同じ温度であっ た. 日平均温度で久ると, 無処理区では $30.4^{\circ} \mathrm{C}$, 終日冷却 区では $25.7^{\circ} \mathrm{C}$, 昼間冷却区では $27.5^{\circ} \mathrm{C}$, 夜間冷却区では

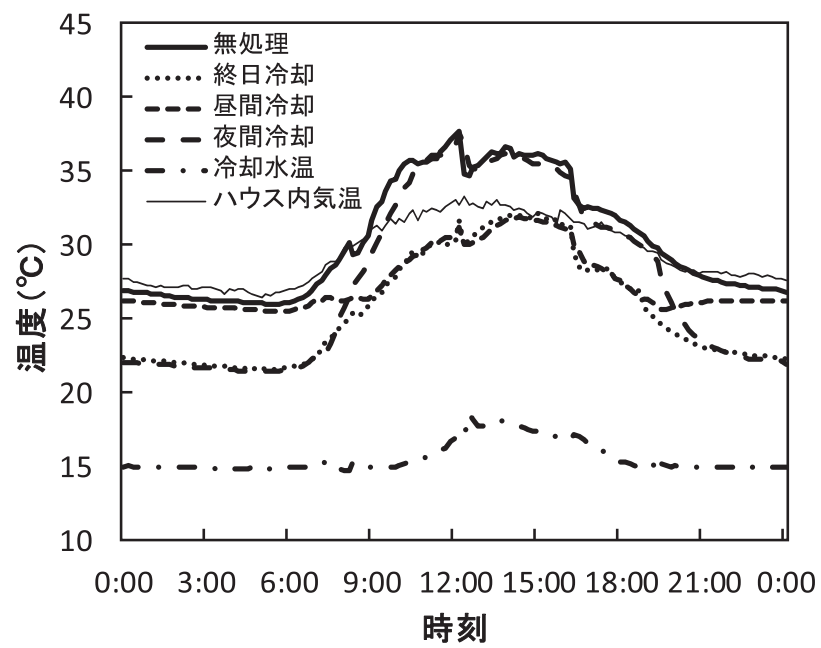

第 2 図 根域冷却の時間帯が根域温度に及ぼす影響（実験 1) 実験期間全体での平均值として示した

$27.6^{\circ} \mathrm{C}$ であった.

第 1 表に定植時の生育，苗の引き抜き抵抗值拉よび第 1 花房着生葉位を示した，茎長は，無処理区，終日冷却区打 よび夜間冷却区の間には有意差がなかったが，昼間冷却区 では他の区に比べて大きかった．葉数については処理区間 で有意差がなかった．地上部乾物重は無処理区と終日冷却 区では有意差がなく, それらに比べて昼間冷却区で大きく, 夜間冷却区で小さかった．根乾物重は，昼間冷却区で最も 大きく，次いで終日冷却区で大きく，無処理区抢よび夜間 冷却区は注涪同等で他の区ょりも小さかった，T/R 比は, 根域冷却を行った処理区間には有意差がなく，それらに比 べて無処理区で大きかった。苗の引き抜き抵抗值は，無処

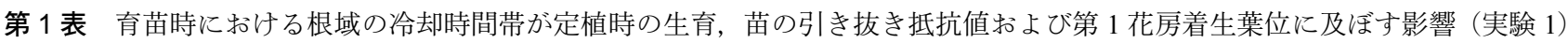

\begin{tabular}{|c|c|c|c|c|c|c|c|}
\hline 処理区 & $\begin{array}{l}\text { 茥長 } \\
(\mathrm{cm})\end{array}$ & 葉数 ${ }^{\mathrm{z}}$ & $\begin{array}{l}\text { 地上部 } \\
\text { 乾物重 } \\
(\mathrm{g} / \text { 株 })\end{array}$ & $\begin{array}{c}\text { 根乾物重 } \\
(\mathrm{g} / \text { 株 })\end{array}$ & $\mathrm{T} / \mathrm{R}$ 比 & $\begin{array}{c}\text { 引き抜き } \\
\text { 抵抗值 }^{\mathrm{y}} \\
(\mathrm{N})\end{array}$ & $\begin{array}{l}\text { 第 } 1 \text { 花房 } \\
\text { 着生葉位 }\end{array}$ \\
\hline 無処理区 & $25.9 b^{x}$ & $8.0 \mathrm{a}$ & $0.75 \mathrm{~b}$ & $0.14 \mathrm{c}$ & $5.3 \mathrm{a}$ & $10.3 \mathrm{~b}$ & $11.1 \mathrm{a}$ \\
\hline 終日冷却区 & $26.7 \mathrm{~b}$ & $8.1 \mathrm{a}$ & $0.77 \mathrm{~b}$ & $0.20 \mathrm{~b}$ & $3.9 \mathrm{~b}$ & $11.3 \mathrm{ab}$ & $10.3 \mathrm{a}$ \\
\hline 昼間冷却区 & $30.6 \mathrm{a}$ & $8.3 \mathrm{a}$ & $0.99 \mathrm{a}$ & $0.24 \mathrm{a}$ & $4.1 \mathrm{~b}$ & $13.0 \mathrm{a}$ & $10.7 \mathrm{a}$ \\
\hline 夜間冷却区 & $25.7 \mathrm{~b}$ & $7.8 \mathrm{a}$ & $0.58 \mathrm{c}$ & $0.15 \mathrm{c}$ & $4.0 \mathrm{~b}$ & $9.9 \mathrm{~b}$ & $10.9 \mathrm{a}$ \\
\hline
\end{tabular}

$\mathrm{z}$ 先端小葉の葉身長が $20 \mathrm{~mm}$ 以上である葉の数

$\mathrm{y}$ 定植 1 週間後の値

$\mathrm{x}$ 同一列の異なる符号間に 5\%水準で有意差あり（Tukey 検定， $\mathrm{n}=10$ および 3 ）

第 2 表 育苗時における根域の冷却時間帯が果房別の果実収量に及ぼす影響（実験 1)

\begin{tabular}{|c|c|c|c|c|c|c|c|c|c|c|c|c|c|c|c|c|}
\hline \multirow{2}{*}{ 処理区 } & \multicolumn{4}{|c|}{ 総収量（g／株） } & \multicolumn{4}{|c|}{ 可販果収量 $(\mathrm{g} / \text { 株 })^{\mathrm{z}}$} & \multicolumn{4}{|c|}{1 果重 ( $\mathrm{g} /$ 個 $)^{\mathrm{y}}$} & \multicolumn{4}{|c|}{ 可販果個数（個／株） } \\
\hline & 第 1 果房 & 第 2 果房 & 第 3 果房 & 合計 & 第 1 果房 & 第 2 果房 & 第 3 果房 & 合計 & 第 1 果房 & 第 2 果房 & 第 3 果房 & 全平均 & 第 1 果房 & 第 2 果房 & 第 3 果房 & 合計 \\
\hline 無処理区 & $503 a^{x}$ & $453 \mathrm{ab}$ & $498 \mathrm{a}$ & $1453 \mathrm{~b}$ & $461 \mathrm{a}$ & $453 a b$ & $485 \mathrm{a}$ & $1399 \mathrm{~b}$ & $153 \mathrm{a}$ & $151 \mathrm{a}$ & $151 \mathrm{a}$ & $151 \mathrm{a}$ & $3.1 \mathrm{a}$ & $3.0 \mathrm{~b}$ & $3.3 \mathrm{a}$ & $9.3 \mathrm{~b}$ \\
\hline 終日冷却区 & $485 \mathrm{a}$ & $421 \mathrm{~b}$ & $510 \mathrm{a}$ & $1415 \mathrm{~b}$ & $474 \mathrm{a}$ & $417 \mathrm{~b}$ & $503 \mathrm{a}$ & $1394 \mathrm{~b}$ & $143 \mathrm{a}$ & $152 \mathrm{a}$ & $151 \mathrm{a}$ & $148 \mathrm{a}$ & $3.3 \mathrm{a}$ & $2.8 \mathrm{~b}$ & $3.4 \mathrm{a}$ & $9.5 \mathrm{~b}$ \\
\hline 昼間冷却区 & $549 \mathrm{a}$ & $543 \mathrm{a}$ & $563 \mathrm{a}$ & $1655 \mathrm{a}$ & $541 \mathrm{a}$ & $533 \mathrm{a}$ & $549 \mathrm{a}$ & $1623 \mathrm{a}$ & $139 \mathrm{a}$ & $148 \mathrm{a}$ & $143 \mathrm{a}$ & $143 \mathrm{a}$ & $3.9 \mathrm{a}$ & $3.6 \mathrm{a}$ & $3.8 \mathrm{a}$ & $11.3 \mathrm{a}$ \\
\hline 夜間冷却区 & $438 \mathrm{a}$ & $404 \mathrm{~b}$ & $503 \mathrm{a}$ & $1344 \mathrm{~b}$ & $432 \mathrm{a}$ & $404 \mathrm{~b}$ & $503 \mathrm{a}$ & $1338 \mathrm{~b}$ & $139 \mathrm{a}$ & $138 \mathrm{a}$ & $134 \mathrm{a}$ & $136 \mathrm{a}$ & $3.1 \mathrm{a}$ & $2.9 \mathrm{~b}$ & $3.8 \mathrm{a}$ & $9.8 \mathrm{~b}$ \\
\hline
\end{tabular}

\footnotetext{
${ }^{\mathrm{z}} 80 \mathrm{~g}$ 以上の正常果の全収量

${ }^{\mathrm{y}} 80 \mathrm{~g}$ 以上の正常果の重量

$\mathrm{x}$ 同一列の異なる符号間に 5\%水準で有意差あり（Tukey 検定， $\mathrm{n}=3$ ）
} 
理区と夜間冷却区に比べて昼間冷却区で大きかった，第 1 花房着生葉位には処理区間で有意差がなかった。

第 2 表に果実収量を示した。株当たりの総収量および可 販果收量は, 無処理区, 終日冷却区および夜間冷却区の間 には有意差がなく，それらに比べて昼間冷却区で大きかっ た．果房別でみると，第 1 果房拈よび第 3 果房には処理区 間で有意差がなかったが, 第 2 果房に打ける総收量打よび 可販果収量は, 無処理区と各根域冷却処理区との間には有 意差はないものの, 終日冷却区打よび夜間冷却区と比べる と昼間冷却区で大きかった。 可販果収量の構成要素として 1 果重挹よび可販果個数に分けて比較すると, 1 果重はいず れの果房でも処理区間に有意差がなかったが, 第 2 果房お よび合計の可販果個数は無処理区，終日冷却区および夜間 冷却区の間に有意差がなく，それらに比べて昼間冷却区に おいて多かった。

\section{2. 昼間の根域冷却時間の長さが苗の生育および定植後の 果実収量に及ぼす影響（実験 2)}

第3図にポット育苗期間平均での根域温度などを示した。 冷却時間帯の冷却水温度は注涪設定した $15^{\circ} \mathrm{C}$ に維持でき た. 根域温度を冷却時間帯の平均でみると, $8 \mathrm{~h}$ 冷却区では 無処理区 $\left(38.5^{\circ} \mathrm{C}\right)$ より $3.0^{\circ} \mathrm{C}$ 低い $35.5^{\circ} \mathrm{C}, 12 \mathrm{~h}$ 冷却区では 無処理区 $\left(35.5^{\circ} \mathrm{C}\right)$ より $3.5^{\circ} \mathrm{C}$ 低い $33.0^{\circ} \mathrm{C}$ であった. 冷却 を行わない時間帯については, 無処理区とほぼ同じ根域温 度で推移した. 日平均温度でみると, 無処理区では $31.4^{\circ} \mathrm{C}$, $8 \mathrm{~h}$ 冷却区では $30.0^{\circ} \mathrm{C}, 12 \mathrm{~h}$ 冷却区では $29.5^{\circ} \mathrm{C}$ であった.

第 3 表に定植時の生育, 苗の引き抜き抵抗值拉よび第 1 花房着生葉位を示した. 茎長打よび地上部乾物重は, 無処 理区に比べて根域冷却処理区で大きく, 冷却処理区間には 有意差がなかった. 葉数については, 無処理区に比べて $8 \mathrm{~h}$

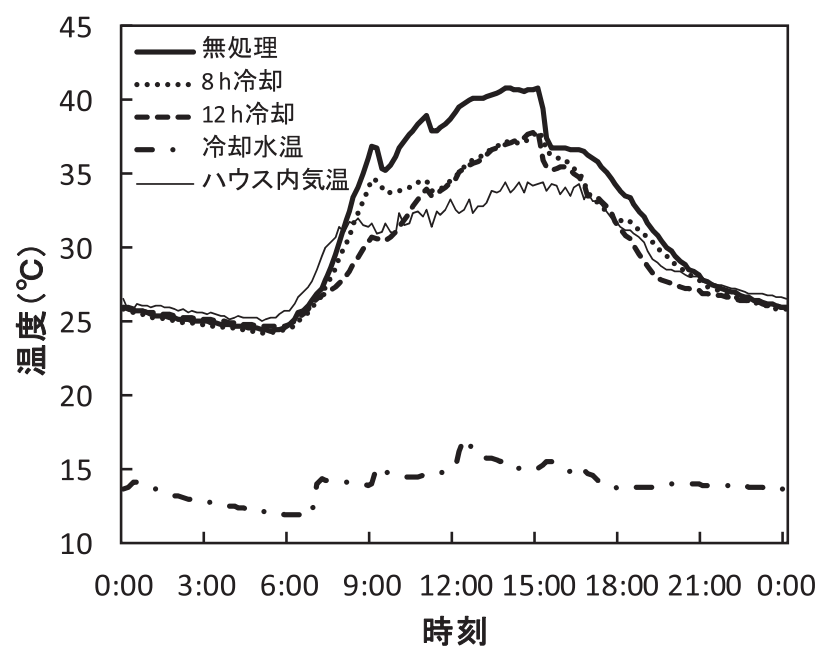

第3 図 根域冷却時間の長さが根域温度に及ぼす影響(実験2) 実験期間全体での平均值として示した

冷却区で多く，それらの処理区と $12 \mathrm{~h}$ 冷却区の間に有意差 がなかった．根乾物重は，無処理区に比べて $12 \mathrm{~h}$ 冷却区で 大きく, そ机らの处理区と $8 \mathrm{~h}$ 冷却区の間に有意差がなかっ た． T/R 比には処理区間で有意差がなかった．苗の引き抜 き抵抗值は，無処理区に比べて根域冷却処理区で大きく， 冷却処理区間では $12 \mathrm{~h}$ 冷却区の方が大きかった．また，第 1 花房着生葉位には処理区間差がなかった.

第 4 表に果実収量を示した．株当たりの総収量および可 販果収量は, 無処理区に比べると根域冷却処理区で大きく, 冷却処理区間には有意差がなかった，果房別でみると，第 2 果房の総収量怙よび可販果収量は無処理区と $12 \mathrm{~h}$ 冷却区 の間には有意差がなく，それらに比べて $8 \mathrm{~h}$ 冷却区で大き

第 3 表 育苗時に抢ける根域の冷却時間の長さが定植時の生育，苗の引き抜き抵抗值怙よび第 1 花房着生葉位に及活す影響 (実験 2)

\begin{tabular}{|c|c|c|c|c|c|c|c|}
\hline 処理区 & $\begin{array}{l}\text { 茎長 } \\
(\mathrm{cm})\end{array}$ & 葉数 ${ }^{\mathrm{z}}$ & $\begin{array}{l}\text { 地上部 } \\
\text { 乾物重 } \\
(\mathrm{g} / \text { 株 })\end{array}$ & $\begin{array}{c}\text { 根乾物重 } \\
(\mathrm{g} / \text { 株 })\end{array}$ & $\mathrm{T} / \mathrm{R}$ 比 & $\begin{array}{c}\text { 引き抜き } \\
\text { 抵抗値 }^{y} \\
(\mathrm{~N})\end{array}$ & $\begin{array}{l}\text { 第 } 1 \text { 花房 } \\
\text { 着生葉位 }\end{array}$ \\
\hline 無処理区 & $17.7 b^{x}$ & $6.4 \mathrm{~b}$ & $0.48 \mathrm{~b}$ & $0.11 \mathrm{~b}$ & $4.4 \mathrm{a}$ & $7.1 \mathrm{c}$ & $10.4 \mathrm{a}$ \\
\hline $8 \mathrm{~h}$ 冷却区 & $20.5 \mathrm{a}$ & $7.4 \mathrm{a}$ & $0.63 \mathrm{a}$ & $0.13 \mathrm{ab}$ & $4.8 \mathrm{a}$ & $9.0 \mathrm{~b}$ & $9.8 \mathrm{a}$ \\
\hline $12 \mathrm{~h}$ 冷却区 & $20.6 \mathrm{a}$ & $7.2 \mathrm{ab}$ & $0.65 \mathrm{a}$ & $0.16 \mathrm{a}$ & $4.1 \mathrm{a}$ & $12.1 \mathrm{a}$ & $9.9 \mathrm{a}$ \\
\hline
\end{tabular}

$\mathrm{z}$ 先端小葉の葉身長が $20 \mathrm{~mm}$ 以上である葉の数

$\mathrm{y}$ 定植 1 週間後の值

$\mathrm{x}$ 同一列の異なる符号間に 5\%水準で有意差あり（Tukey 検定, $\mathrm{n}=10$ 抢よび 3 ）

第 4 表 育苗時における根域の冷却時間の長さが果房別の果実収量に及ぼす影響（実験 2）

\begin{tabular}{|c|c|c|c|c|c|c|c|c|c|c|c|c|c|c|c|c|}
\hline \multirow{2}{*}{ 処理区 } & \multicolumn{4}{|c|}{ 総収量（g／株） } & \multicolumn{4}{|c|}{ 可販果収量 $(\mathrm{g} / \text { 株 })^{\mathrm{z}}$} & \multicolumn{4}{|c|}{1 果重 $(\mathrm{g} /$ 個) y } & \multicolumn{4}{|c|}{ 可販果個数（個／株） } \\
\hline & 第 1 果房 & 第 2 果房 & 第 3 果房 & 合計 & 第 1 果房 & 第 2 果房 & 第 3 果房 & 合計 & 第 1 果房 & 第 2 果房 & 第 3 果房 & 全平均 & 第 1 果房 & 第 2 果房 & 第 3 果房 & 合計 \\
\hline 無処理区 & $369 a^{x}$ & $328 \mathrm{~b}$ & $355 \mathrm{~b}$ & $1052 \mathrm{~b}$ & $260 \mathrm{a}$ & $292 \mathrm{~b}$ & $327 \mathrm{c}$ & $879 \mathrm{~b}$ & $104 \mathrm{a}$ & $114 \mathrm{~b}$ & $118 \mathrm{c}$ & $112 \mathrm{~b}$ & $2.5 \mathrm{a}$ & $2.6 \mathrm{a}$ & $2.8 \mathrm{a}$ & $7.8 \mathrm{a}$ \\
\hline $8 \mathrm{~h}$ 冷却区 & $316 \mathrm{a}$ & $426 \mathrm{a}$ & $448 \mathrm{ab}$ & $1190 \mathrm{a}$ & $244 \mathrm{a}$ & $404 \mathrm{a}$ & $408 \mathrm{~b}$ & $1056 \mathrm{a}$ & $116 \mathrm{a}$ & $143 \mathrm{a}$ & $141 \mathrm{~b}$ & $136 \mathrm{a}$ & $2.2 \mathrm{a}$ & $2.9 \mathrm{a}$ & $2.9 \mathrm{a}$ & $8.0 \mathrm{a}$ \\
\hline $12 \mathrm{~h}$ 冷却区 & $369 \mathrm{a}$ & $329 \mathrm{~b}$ & $592 \mathrm{a}$ & $1289 \mathrm{a}$ & $264 \mathrm{a}$ & $302 \mathrm{~b}$ & $538 \mathrm{a}$ & $1104 \mathrm{a}$ & $99 \mathrm{a}$ & $113 \mathrm{~b}$ & $169 \mathrm{a}$ & $130 \mathrm{ab}$ & $2.7 \mathrm{a}$ & $2.7 \mathrm{a}$ & $3.2 \mathrm{a}$ & $8.5 \mathrm{a}$ \\
\hline
\end{tabular}

${ }^{\mathrm{z}} 80 \mathrm{~g}$ 以上の正常果の全収量

${ }^{\mathrm{y}} 80 \mathrm{~g}$ 以上の正常果の重量

$\mathrm{x}$ 同一列の異なる符号間に $5 \%$ 水準で有意差あり（Tukey 検定， $\mathrm{n}=3$ ） 
かった. 第 3 果房の総収量は, 無処理区に比べて $12 \mathrm{~h}$ 冷却 区で大きく，それらの処理区と $8 \mathrm{~h}$ 冷却区の間には有意差 がなかった. 第 3 果房の可販果収量は, 無処理区に比べる と根域冷却処理区で大きく, 冷却処理区間では $12 \mathrm{~h}$ 冷却区 の方が大きかった. 可販果収量の構成要素として 1 果重お よび可販果個数に分けて比較すると, 1 果重は, 第 2 果房 では無処理区と $12 \mathrm{~h}$ 冷却区には有意差がなく, それらに比 べて $8 \mathrm{~h}$ 冷却区で大きく, 第 3 果房では無処理区に比べる と根域冷却処理区で大きく, 冷却処理区間では $12 \mathrm{~h}$ 冷却区 の方が大きかった. 全平均の 1 果重は, 無処理区に比べて $8 \mathrm{~h}$ 冷却区で大きく, それらの処理区と $12 \mathrm{~h}$ 冷却区の間に は有意差がなかった. 一方, 可販果個数にはいずれの果房 でも処理区間差がなかった。

\section{考察}

これまで，トマト，イチゴ，ホウレンソウなどでは，夏 季高温期の根域冷却によって生育の促進, 増収あるいは開 花の前進化などの効果が認められることが報告されている (Ikeda ら, 2007; Lee・Takakura, 1994; 中野ら, 2009; 佐々木, 1991; 佐々木・板木, 1989; 和田，2004; 山崎ら，2007; 安場 ら, 2006). 本研究でもこれまでの報告と同様にトマト育苗 時の根域冷却によって生育が促進されることが明らかと なった。実験 1 では，試作した根域冷却装置を用いて㡺間 および夜間の冷却を行った結果，それぞれの冷却時間帯に おける根域温度を平均で約 $4.5^{\circ} \mathrm{C}$ 下げることができた。

昼間冷却区では，無処理区よりも地上部，根ともに生育 が促進され，生育促進効果が最も高かった．本実験のよう に黒色ポリエチレン製ポットを用いた育苗では，ポットの 集熱効果で特に昼間の根域温度が上がりやすい. 高地温下 では，光合成に関わる要因である Rubisco 活性の低下（Xu ら, 2002) やクロロフィル含量の減少 (Du・Tachibana, 1994; Ruter・Ingram, 1992; Xu ら，2002)，あるいは光合成が抑制 されることが報告されている（Du・Tachibana, 1994; He ら， 2001)。また，養分の吸収は主に昼間に行われ，特に夏季高 温期はその傾向が大きい（Terabayashi ら，1991）が, 根域 温度が高すぎると養分吸収が抑えられる(Tindall ら, 1990)。 一方，低温期に根域を加温する場合には，夜間よりも昼間 の加温の方が生育促進に対する効果は高いとされている (Gent・Ma, 2000）。以上のことから，昼間のみの冷却によ る生育促進効果が高かったと考えられる.

一方, 終日冷却区では, 無処理区に比べて根の生育が促 進されるのみの効果にとどまり, 夜間冷却区では無処理区 よりも地上部の生育が抑えられた. 従って, 夜間の冷却に よって相対的に地上部の生育が抑制される傾向にあった. トマトの幼植物において, 終日一定の温度管理を行った場 合, 地上部, 地下部ともに生育に適した根域温度は 25 $30^{\circ} \mathrm{C}$ であると藤重ら（1991）は報告している，また，Tindal ら（1990）は，トマトの生育や養分吸収が最も大きい根域 温度は $25^{\circ} \mathrm{C}$ 程度であると述べており, Hurewitz・Janes (1983)
は, $30^{\circ} \mathrm{C}$ がトマトの生育や光合成速度が最も大きくなる根 域温度であると述べている，以上のことから，報告によっ て多少の相違はあるが, 終日一定の温度管理の場合には, トマト幼植物の生育や養分吸収, あるいは光合成にとって は， $25 \sim 30^{\circ} \mathrm{C}$ 程度が最も適した根域温度であると考えら れる. 従って, 本実験において昼間の根域冷却は根域温度 を適温に近づけるよらな処理であったのに対し，夜間の根 域冷却は，根域適温を下回らせるよらな温度管理であった と考えられる，夜間の根域温度が昼間の光合成に直接影響 を及ぼすとは考えにくいため，養分吸収の減少など他の要 因が地上部の生育抑制の理由として推察される.

しかし, 夜間に冷却を行った場合の根域温度は $22 \sim 23^{\circ} \mathrm{C}$

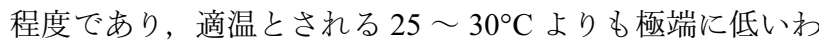
けではなかった。一般に苗の生育が進むと根の分布はポッ トの外縁部や底面に集中するようになる，本実験による観 察の結果でもそのよらな傾向が見られた。本研究では培地 中央部の温度を測定したが，本冷却方式では，冷却管が接 するポット外縁部の根域温度は，培地中央部に比べて低 かったと考えられる，従って，夜間に冷却した場合，根が 多く分布する部分に打いて，測定值よりも低い值で根域温 度が推移したために生育が抑制されたと推察される。

本実験の環境条件下では，夜間の根域冷却は地上部の生 育に抑制的に作用すると考えられたが，夜間に冷却を行っ た終日冷却区や夜間冷却区では，無処理区に比べると T/R 比が小さく相対的に根の生育が良かった。. 低温期のイチゴ 栽培では, 夜間の根温が高いほど根の生育が抑制されるが, それは根の呼吸が大きいためであると宇田川（1991）は報 告している．作物や環境条件が異なるが，本実験において も夜間の冷却は根の呼吸を抑制し，地上部に比べて根の生 育を促進した可能性がある。しかし，本実験の環境条件下 では，地上部の生育が抑制される傾向にあったため，夜間 の根域冷却は必要ないと考えられた。

さらに実験 2 では，昼間の根域冷却について $12 \mathrm{~h} （ 7: 00$ 〜 19:00）の冷却から根域の温度が上がりやすい時間帯 （9:00〜 17:00）のみに短縮することを試みた. その結果, 地上部，根ともに $12 \mathrm{~h}$ の冷却とほぼ同じ生育を示し，本実 験条件下では，9:00〜 17:00の8h のみの根域冷却でも十 分生育促進効果があると考えられた. $8 \mathrm{~h}$ 冷却区と $12 \mathrm{~h}$ 冷 却区の間に抢ける日平均根域温度の差は $0.5^{\circ} \mathrm{C}$ とさく, そのため両処理区間の生育差が小さかったと考えられる.

本研究では，夏季高温期に問題になりやすい苗の活着に ついても苗の引き抜き抵抗值を指標として検討を行った. 実験 1 および 2 とも根乾物重が大きい汪ど引き抜き抵抗值 も大きい傾向にあり，苗の段階で根量が多くなったことで 定植後の根張りが良くなったと推察された。従って，ポッ 卜育苗時に扣ける昼間のみの冷却は地上部の生育を損ねる ことなく活着を促進させる方法としても効果的であると考 えられた。

実験 1 および 2 とも，処理区間で第 1 花房着生葉位に有 
意差はなかった．第 1 花房着生葉位の変動には気温が大き く影響するが，根域温度はほとんど影響しないと報告され て扣り（Phatak ら，1966; 加藤，1964, 藤井ら， 1962; 藤重 ら，1991），本実験の結果と一致する.

本実験では, 定植後は固形培地耕による 3 段密植栽培を 行った. 鈴木ら（2011）は, NFT 方式による 3 段密植栽培 では定植苗の生育は果実収量に影響を及ぼさず，それは固 形培地耕や土耕に比べて根の伸長の制限が少なく苗の生育 状況の影響を比較的受けにくいためと述べている。一方, 固形培地耕（中林ら，1990）拈よび土耕（Fierro ら，1994） では, 定植苗の生育が良い方が初期収量は高いと報告され ている. 本実験でも, 概ね定植苗の生育, 特に地上部の生 育が良い区臣可販果収量は高い傾向にあった。従って, 昼間の夕根域冷却を行った処理区に打いて可販果収量が高 かったのは，他の処理区よりも生育の良い苗が得られたこ とが要因のひとつと考えられる.

可販果収量をその構成要素である 1 果重および可販果個 数に分けると, 実験 1 では可販果個数が, 実験 2 では 1 果 重が増えたことが増収の要因であった．実験によって要因 が異なるものの, 処理区間で 1 果重や可販果個数に差がみ られたのは，第 $2 \sim 3$ 果房であった. トマトでは, 環境条 件にもよるが， 4 葉期に第 1 花房が分化し，その後 7 葉期 に第 2 花房, 10 葉期に第 3 花房が分化する（齋藤，2004）. また。苗の生育状態, 特に地上部の生育は花芽の発達に影 響し，花芽の発育は着果した果実の肥大にも影響を及ぼす (齋藤， 2004). 本実験では $7 〜 8$ 葉期の定植期からその直 後に打いて処理区間に拈ける生育の差が最も大きかったと 考えられる. 従って, 定植時に地上部の生育が良かった区 に拈いて第 $2 \sim 3$ 果房の花芽の発達や果実肥大が他の区に 比べて優れ, 着果数や 1 果重が大きくなった可能性がある. また，一般に定植後の環境条件の違いが着果や果実肥大へ 及ぼす影響も大きく，それが増収の要因の違いにつながっ た可能性が考兄らるが，本実験の結果からはそれを明ら かすることはできなかった。 このため，育苗時の根域冷却 と定植後の果実収量との関係についてより詳細な検討が必 要であろう。

一方, 本研究の範囲では, 根域温度をどの程度低下させ るのが最も生育促進や収量増加に効果があるのかは明らか ではなかったため, 根域冷却の適切な温度範囲についてさ らに検討する必要がある.

以上のことから，夏季高温期に打ける黒色ポリエチレン 製ポットを用いたトマト育苗において, 本実験条件下では, 昼間の $12 \mathrm{~h} （ 7: 00 \sim 19: 00 ） の$ 久培地中央部の根域温度を 3 $\sim 4^{\circ} \mathrm{C}$ 程度低下させることで苗の生育が促進され, 定植後 の活着が良くなるとともに果実収量も増加することが明ら かとなった，さらに，根域温度が特に上昇しやすい 9:00〜 17:00の $8 \mathrm{~h}$ の久根域を冷却させるだけでも $12 \mathrm{~h} （ 7: 00 〜$ 19:00）の冷却とほぼ同等の効果が得られた。 このよらに根 域冷却の効果の高い時間帯のみ冷却を行らことで，冷却に
用いる資源やエネルギーの節約あるいは冷却コストの低減 につながることが期待される。また，本実験で用いた冷却 装置は，塩化ビニール製パイプなどの安価な資材を用いた もので, 冷却水として自然冷水である地下水や湧水などを 活用できれば，低コストで導入しやすいシステムであると 考えられる.

\section{摘 要}

黒色ポリエチレン製ポットを用いた夏季高温期のトマト 育苗に扔いて, 根域冷却を行ら時間帯が苗の生育・活着お よび果実収量に及ぼす影響について検討した。根域冷却は ポットの脇に設置した塩化ビニール製パイプ内に $15^{\circ} \mathrm{C} の$ 冷却水を循環することで行った. 終日冷却では, 無処理に 比べて根の生育が促進されるのみの効果にとどまったが, 昼間（7:00〜 19:00）の夕の冷却によって, 無処理よりも 根に加えて地上部の生育が促進され, 終日冷却以上に生育 促進効果が高かった。 一方，夜間（19:00〜 7:00）のみの 冷却は，地上部の生育を抑制した。 また，根域冷却によっ て根の生育が促進されることで活着が良くなることが分 かった，さらに，育苗期の昼間の冷却によって果実収量が 増加することが明らかとなった。 昼間でも特に根域温度が 上昇する時間帯 $(9: 00 〜 17: 00)$ のみの冷却でも 7:00〜 19:00の冷却とほぼ同等の効果が得られた。 これらの結果 から，本実験の環境条件下に拈けるトマトのポット育苗に 颃いて, 9:00〜 17:00の $8 \mathrm{~h}$ の夕平均で $3 \sim 4{ }^{\circ} \mathrm{C}$ 程度培地 中央部の根域を冷却することで生育が促進され，低段密植 栽培に打ける果実収量も増加寸ることが明らかとなった。

\section{引用文献}

Ali, I. A., U. Kafkafi, Y. Sugimoto and S. Inanaga. 1994. Response of sand-grown tomato supplied with varying ratios of nitrate/ammonium to constant and variable root temperatures. J. Plant Nutr. 17: 2001-2024.

Du, Y. C. and T. Tachibana. 1994. Photosynthesis, photosynthase transolocation and metabolism in cucumber roots held at supraoptimal temperature. J. Japan. Soc. Hort. Sci. 63: 401408.

Fierro, A., N. Trembley and A. Gosselin. 1994. Supplemental carbon dioxide and light improved tomato and pepper seedling growth and yield. HortScience 29: 152-154.

藤井健雄 - 伊藤 正 - 椎名不二雄 - 湊 莞爾. 1962. 果菜 栽培温度に関する研究.（1）。トマト, キゥリの育苗に おける気温, 地温の影響について. 千葉大園学報. 10: 59-70.

藤重宣昭・杉山直儀・尾形亮輔. 1991. トマトの花芽分化 と結実に及ぼす根温の影響. 園学雑. 60: 97-103.

Gent, M. P. N. and Y-Z. Ma. 2000. Mineral nutrition of tomato under diurnal temperature variation of root and shoot. Crop Sci. 40: 1629-1636. 
He, J., S. K. Lee and I. C. Dodd. 2001. Limitations to photosynthesis of lettuce grown under tropical conditions: alleviation by root-zone cooling. J. Exp. Bot. 359: 1323-1330.

Hurewitz, J. and H. W. Janes. 1983. Effect of altering the rootzone temperature on growth, translocation, carbon exchange rate, and leaf starch accumulation in the tomato. Plant Physiol. 73: 46-50.

Ikeda, T., K. Yamazaki, H. Kumakura and H. Hamamoto. 2007. Effects of cooling of medium on fruit set in high-bench strawberry culture. HortScience 42: 88-90.

石川順也・山中正仁. 2009. 生産用培養土のマサ土比率が 定植後のニチニチソウ拈よびパンジーの生育に及ぼす 影響. 兵庫農技総七研報（農業）．57：15-18.

岩瀬博貞 - 杉浦 悟 - 矢部和則 - 桜井雍三 - 大須賀源芳. 1983. 高温期に打けるトマトの夜冷育苗に関する研究 （第2 報）土壌水分及び施肥量の影響. 愛知農総試研報. 15: 204-210.

加藤 徹. 1964. 野菜育苗中の地温, 気温と苗の生態との 関係. 農及園. 39: 1135-1136.

木村 進・戸田幹彦・岩崎正男・野中民雄・永嶋芳樹. 1978. 盛夏期の夜冷育苗がトマト ‘ファースト’の生育・収 量に及ぼす影響. 静岡農試研報. 23: 32-39.

木下貴文・東出忠桐・藤野雅丈・伊吹俊彦・笠原賢明. 2010 . 冬春セルリ一栽培に打ける傾斜地養液栽培システムの 性能抢よび根域加温の時間帯の効果. 園学研. 9: 53-58.

Lee, Y. D. and T. Takakura. 1994. Root cooling for spinach in deep hydroponic culture under high air temperature conditions. Acta Hortic. 399: 121-126.

中林和重・山崎邦典・北島滋宣. 1990. トマトのロックウー ル栽培にお打る育苗方法の違いが生育と収量に及ぼす 影響. 土肥誌. 61:260-264.

中野善公・前田茂一・後藤丹十郎・東出忠桐 - 木下貴文・ 吉川弘恭. 2009. 培地水分の気化促進処理が高温期に おける培地温度扎よびパンジー， ミニシクラメンの生 育に及ぼす影響. 園学研. 8: 475-481.

Oda, M., K. Kitada, T. Ozawa and H. Ikeda. 2005. Initiation and development of flower truss in 'Momotaro' tomato plants associated with night temperature, and decrease in the number of leaves under the first truss by raising plug seedlings at a cool highland. J. Japan. Soc. Hort. Sci. 74: 42-46.

大山克己・古在豊樹 ・全 昶厚. 2003. 閉鎖型苗生産シス テムの開発およびその利用. 植物工場学会誌. 15: 1-10.

Phatak, S. C., S. H. Wittwer and F. G. Teubner. 1966. Top and root temperatures effects on tomato flowering. Proc. Amer. Soc. Hort. Sci. 88: 527-531.

Ruter, J. M. and D. L. Ingram. 1992. High root-zone temperatures influence $\mathrm{RuBisCO}$ activity and pigment accumulation in leaves of 'Rotundifolia' holly. J. Amer. Soc. Hort. Sci.
117: 154-157.

齋藤 隆. 2004. 生育のステージと生理, 生態. p. 19-169. 農文協編. 野菜園芸大百科第2 版 第2巻トマト. 農文協. 東京.

桜井雍三・坂森正博 - 矢部和則 - 山口久夫 - 大須賀源芳. 1978. 高温期に扣けるトマトの夜冷育苗に関する研究 (第 1 報) 夜冷効果と処理方法について. 愛知農総試研 報. B10: 8-14.

佐々木皓二. 1991. NFTを用いた 2 段摘心栽培によるトマ 卜の周年計画生産技術の確立. 生物環境調節. 29: 117126.

佐々木皓二・板木利隆. 1989. 養液栽培における夏期の地 下部冷却が果菜類の生育, 収量に及ぼす影響. 生物環 境調節. 27: 89-95.

島 浩二・川西孝秀・矢部泰弘・森下照久・藤井一徳・後 藤丹十郎. 2008. 熱融着性ポリエステル繊維固化培地 で育成したパンジーのプランター定植後の生育. 和歌 山農林水技七研報. 9: 15-19.

鈴木克己・水上宏二 - 土屋 和 - 安場健一郎 - 中野有加 高市益行. 2011. トマト低段密植栽培の二次育苗に掠 ける徒長抑制と果実収量について。園学研. 10: 183189.

Terabayashi, S., K. Takii and T. Namiki. 1991. Variations in diurnal uptake of water and nutrients by tomato plants grown hydroponically. J. Japan. Soc. Hort. Sci. 60: 547-553.

Tindall, J. A., H. A. Milles and D. E. Radcliffe. 1990. The effect of root zone temperature on nutrient uptake of tomato. J. Plant. Nutr. 13: 939-956.

土屋 和. 2007. 低段密植栽培システムの開発. 農業機械 学会誌. 69: 13-17.

宇田川雄二. 1991. 根温を異にした養液栽培イチゴの生理 生態学研究. 千葉農試特別研報. 19: 1-60.

和田光生. 2004. トマト・ロックウール栽培での夏季の根 域冷却育苗, 高濃度培養液育苗による高品質苗生産. 農耕と園芸. 59(3): 70-73.

Xu, Q., B. Huang and Z. Wang. 2002. Photosynthetic response of creeping bentgrass to reduced root-zone temperatures at supra optimal air temperature. J. Amer. Soc. Hort. Sci. 127: 754-758.

山崎敬亮・熊倉裕史・濱本 浩. 2007. 促成イチゴの高設 栽培に打ける連続出蕾性に与える定植後の培地昇温抑 制と施肥時期の効果. 近畿中国四国農研報. 7: 35-47. 安場健一郎・屋代幹雄・松尾健太郎. 2006. 多孔質フィル ム製ダクトを使用した冷却チューブによるホウレンソ ウの根域冷却. 園学雑. 75: 109-115.

吉島豊喜・堤 泰之・小野 誠. 2008. トマト夏季育苗に 扣ける熱線遮蔽フィルム天井被覆及び天井散水が生 育・着果に及ぼす影響. 第7 1 回九州農業研究発表会発 表要旨集. 201. 